\title{
A trial of somatic gene targeting in vivo with an adenovirus vector
} Asami Ino1,2, Yasuhiro Naito ${ }^{1,3}$, Hiroyuki Mizuguchi ${ }^{4}$, Naofumi Handa1, Takao Hayakawa ${ }^{5}$ and Ichizo Kobayashi*1,2

\author{
Address: ${ }^{1}$ Department of Medical Genome Sciences, Graduate School of Frontier Science, University of Tokyo \& Institute of Medical Science, \\ University of Tokyo, 4-6-1 Shirokanedai, Minato-ku, Tokyo 108-8639, Japan, ${ }^{2}$ Graduate Program in Biophysics and Biochemistry, Graduate \\ School of Science the University of Tokyo, ${ }^{3}$ Department of Environmental Information, Keio University, 5322 Endo, Fujisawa, Kanagawa 252- \\ 8520, Japan, ${ }^{4}$ Laboratory of Gene Transfer and Regulation, National Institute of Biomedical Innovation, Asagi 7-6-8, Saito, Ibaraki, Osaka 567- \\ 0085, Japan and ${ }^{5}$ Pharmaceuticals and Medical Devices Agency, Shin-Kasumigaseki Bldg. 3-3-2, Kasumigaseki, Chiyoda-ku, Tokyo 100-0013, \\ Japan \\ Email: Asami Ino - ino@nibio.go.jp; Yasuhiro Naito - ynaito@sfc.keio.ac.jp; Hiroyuki Mizuguchi - mizuguch@nibio.go.jp; \\ Naofumi Handa - nhanda@ims.u-tokyo.ac.jp; Takao Hayakawa - hayakawa-takao@pmda.go.jp; Ichizo Kobayashi* - ikobaya@ims.u-tokyo.ac.jp \\ * Corresponding author
}

Published: 12 October 2005

Genetic Vaccines and Therapy 2005, 3:8 doi:10.1186/1479-0556-3-8

This article is available from: http://www.gvt-journal.com/content/3/I/8

(C) 2005 Ino et al; licensee BioMed Central Ltd.

This is an Open Access article distributed under the terms of the Creative Commons Attribution License (http://creativecommons.org/licenses/by/2.0), which permits unrestricted use, distribution, and reproduction in any medium, provided the original work is properly cited.

\begin{abstract}
Background: Gene targeting in vivo provides a potentially powerful method for gene analysis and gene therapy. In order to sensitively detect and accurately measure designed sequence changes, we have used a transgenic mouse system, MutaMouse, which has been developed for detection of mutation in vivo. It carries bacteriophage lambda genome with lac $Z^{+}$gene, whose change to lacZnegative allele is detected after in vitro packaging into bacteriophage particles. We have also demonstrated that gene transfer with a replication-defective adenovirus vector can achieve efficient and accurate gene targeting in vitro.
\end{abstract}

Methods: An $8 \mathrm{~kb}$ long DNA corresponding to the bacteriophage lambda transgene with one of two lacZ-negative single-base-pair-substitution mutant allele was inserted into a replicationdefective adenovirus vector. This recombinant adenovirus was injected to the transgenic mice via tail-vein. Twenty-four hours later, genomic DNA was extracted from the liver tissue and the lambda::lac $Z$ were recovered by in vitro packaging. The lacZ-negative phage was detected as a plaque former on agar with phenyl-beta-D-galactoside.

Results: The mutant frequency of the lac $Z$-negative recombinant adenovirus injected mice was at the same level with the control mouse $(\sim 1 / 10000)$. Our further restriction analysis did not detect any designed recombinant.

Conclusion: The frequency of gene targeting in the mouse liver by these recombinant adenoviruses was shown to be less than $1 / 20000$ in our assay. However, these results will aid the development of a sensitive, reliable and PCR-independent assay for gene targeting in vivo mediated by virus vectors and other means.

\section{Background}

Gene targeting, which is the precise alteration of genomic information by homologous recombination, has provided a powerful means of genetic analysis in 
microorganisms and mammalian systems [1]. In mouse systems, embryonic stem-cell lines modified in vitro can be used to generate mice that are altered at the germ-line level. If the gene targeting of somatic cells is made possible by gene transfer in vivo, it will facilitate the analysis of gene function, and provide a means of gene therapy for genetic and other diseases [2].

There are two major inherent problems with the use of gene targeting in vivo. First, its low efficiency makes it difficult to detect and analyze. A sensitive and accurate measurement system is therefore needed to detect such lowfrequency events. Although there have been several reports of gene targeting in the rat liver with specifically designed oligonucleotides $[3,4]$, their reproducibility remains controversial [5]. PCR-based detection methods might thus be inaccurate and prone to various artifacts. In order to detect and measure gene targeting in mice with sufficient sensitivity, we used a bacteriophage transgenicmouse system, MutaMouse, which has been developed for the detection of mutagenesis in vivo (Figure 1) [6]. The MutaMouse carries tandem repeats of the bacteriophage lambda genome with the lac $Z^{+}$gene, in which the change to a lacZ-negative allele is detected after its in vitro packaging into viable bacteriophage particles.

The second major problem with gene targeting in vivo is that non-homologous recombination is much more frequent than homologous recombination in mammalian cells. Rare accurately modified cells are selected and purified in the case of embryonic stem cells that are treated in vitro. For gene targeting in vivo, imprecise modification would be detrimental for analytical uses and therapeutic purposes. Accurate gene modification has been achieved efficiently using replication-defective adenovirus vectors for gene delivery in vitro $[7,8]$. Fujita and colleagues used a mammalian plasmid as a model target [7]. The gene targeting was frequent $\left(\sim 10^{-4}\right.$ per cell) and analysis of the products revealed that homologous recombination was more frequent than non-homologous recombination. One possible reason for this high accuracy was protection of the viral DNA by the terminal protein, which is covalently attached to the ends of the viral DNA and to other viral proteins during its transfer to the nucleus and target DNA. Breaks in unprotected DNA would lead to nonhomologous recombination.

The adenovirus is useful for gene delivery in vivo because it has a broad host-range, is easy to prepare to a high titer and only rarely integrates into the host genome by nonhomologous recombination $[9,10]$. To date, more than 170 clinical studies have used recombinant adenovirus vectors to express cDNA in humans [11]. Numerous adenovirus-infection experiments have been carried out with mice, and have established that the injection of adenovi-

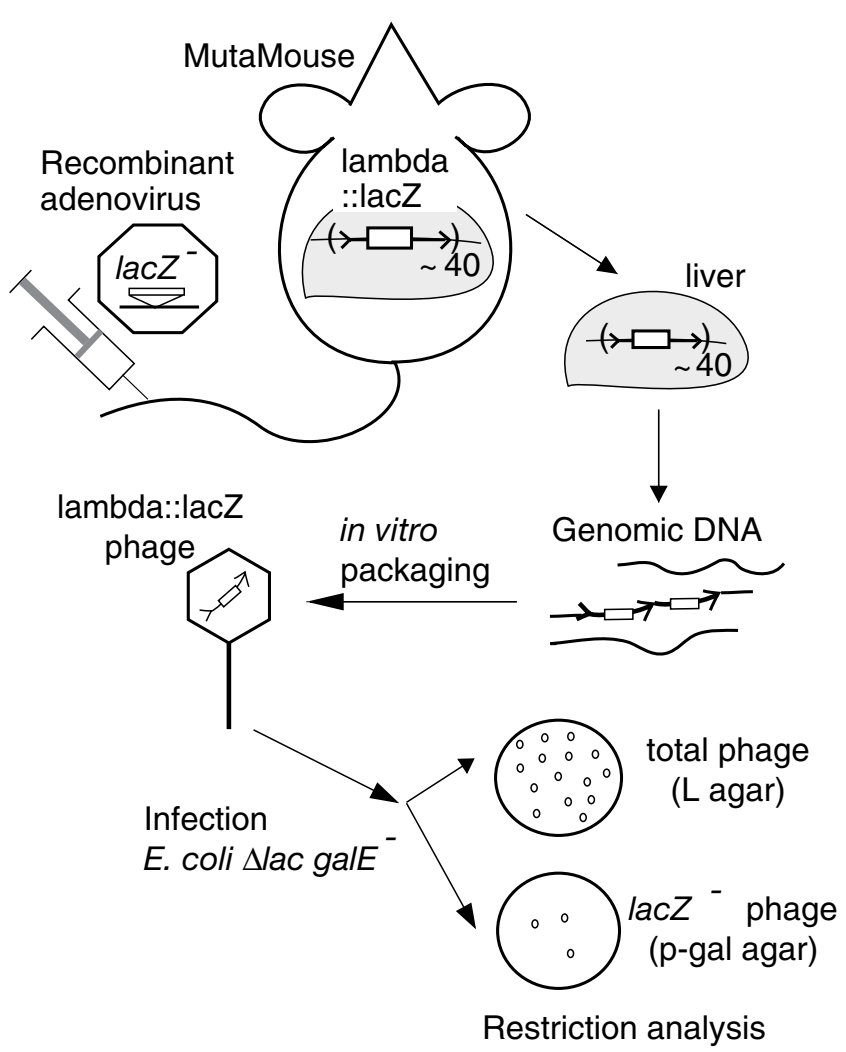

Figure I

Experimental steps to detect gene targeting in vivo. Gene targeting in vivo in liver cells was attempted after the delivery of donor DNA with an adenovirus vector. The gene with the required sequence change (lac Z-) on the lambda transgene in the mouse will be detected after its recovery in bacteriophage particles. Only lacZ-negative mutants can form plaques under the selective conditions.

rus recombinants into the mouse tail-vein leads to the expression of their genes in approximately one-half of the liver cells $[12,13]$.

In the present study, we investigated gene targeting in the mouse liver using a replication-defective adenovirus vector and a transgenic mouse system (Figure 1). Although our initial attempts did not detect the predicted gene targeting (the frequency of the expected recombinants was less than 1/20,000 per lambda genome), the strategy and methods detailed here will aid the development of virusmediated gene targeting in vivo.

\section{Materials and methods}

\section{Bacteria, bacteriophages and plasmids}

The bacteria, bacteriophages and plasmids used in this study are listed together with details of their construction in Additional file 1. 
BIK12001 was used for the titration of bacteriophage lambda and the measurement of lacZ-negative bacteriophage lambda by phenyl beta-D-galactoside (p-gal) selection (see below). BIK1564 was used for the growth of all bacteriophage lambda strains in this study. BIK2206 was used for confirmation of the LacZ-negative phenotype of the bacteriophage selected with p-gal using 5-bromo-4chloro-3-indlyl-beta-D-galactose (X-gal).

The construction of the plasmids used in this study is detailed in additional file 1 . The construction of pAdNY58 is also illustrated in Figure 2. The construction of pAdNY57 was as follows. The SmaI(1)-SacI fragment of LIA7 within the lacZ gene (Figure 2) was used to replace the shorter SmaI-SacI fragment of pUC18. The Glu461Gly mutation (Figure 3) was introduced into the resulting plasmid (pNY15) by site-directed mutagenesis using PCR [14] as follows. The PCR products generated with the primer pair LZG-U (5'-ACCGGCGATGAGCGAA-3') and LZG-MA (5'-GCCTGATCCATTCCCCAGCGACCA-3'), and the primer pair LZG-MS (5'-GGGAATGGATCAGGCCACGGCCGC-3') and LZG-D (5'-GGGCTGGTCTTCATCC-3'), were mixed and used as templates for the second round of PCR with the primer pair LZG-U and LZG-D. The MluI-BssHII fragment of the wild-type lacZ gene of pNY15 was replaced by the MluI-BssHII fragment of the PCR product. The targeted change in the resulting plasmid (pNY15G3.11) was confirmed by sequencing. pNY20 was produced by replacing the smaller SmaI-SacI fragment of pNY19 with the homologous SmaI-SacI fragment of pNY15G3.11, which carries the mutant sequence.

These two lacZ mutations were transferred back to lambda by homologous recombination in vivo [15] in order to generate LIA15 and LIA11, respectively. The recombinational transfer was carried out as follows. Cells of BIK12015 or BIK12018 were grown to $\mathrm{OD}_{600}=\sim 0.3$ in LB (10 g bactotrypton, $5 \mathrm{~g}$ yeast extract and $10 \mathrm{~g} \mathrm{NaCl}$ per liter) containing $20 \mu \mathrm{g} / \mathrm{ml}$ chloramphenicol, $0.2 \% \mathrm{mal}-$ tose and $10 \mathrm{mM} \mathrm{MgSO}_{4}$. LIA7 was adsorbed onto the cells at a multiplicity of 1.0 at $37^{\circ} \mathrm{C}$ for 15 minutes. The mixture was shaken at $37^{\circ} \mathrm{C}$ until the $\mathrm{OD}_{600}$ dropped below 0.3. One drop of $\mathrm{CHCl}_{3}$ was added to the mixture, which was then shaken for 30 seconds. The mixture was centrifuged and the supernatant was recovered. The supernatant was assayed for BIK12001 on agar plates containing p-gal as detailed below. The plaques on the p-gal plates were isolated and analyzed for the designed sequence change by restriction of the PCR products (see Analysis of the mutant bacteriophage DNA).

\section{Selection of lacZ-negative bacteriophage with p-gal}

The lacZ-negative bacteriophage particles were detected using positive selection [15,16]. BIK12001 cells were grown with shaking at $37^{\circ} \mathrm{C}$ to $\mathrm{OD}_{600}=1.0$ in LB contain- ing ampicillin $(50 \mu \mathrm{g} / \mathrm{ml})$, kanamycin $(20 \mu \mathrm{g} / \mathrm{ml})$ and $0.2 \%$ maltose. The culture was centrifuged at $3,500 \mathrm{rpm}$ for 15 minutes at $4{ }^{\circ} \mathrm{C}$. The pellets were dissolved into one-half the volume of $\mathrm{LB}$ containing $10 \mathrm{mM} \mathrm{MgSO}_{4}$. The bacteriophage was adsorbed onto these cells at room temperature for 20 minutes. To estimate the total number of bacteriophages, $2.5 \mathrm{ml}$ molten $1 / 4 \mathrm{LB}$ top agar (5 g LB broth base (Gibco BRL, Rockville, MD, USA), $6.4 \mathrm{~g} \mathrm{NaCl}$ and $7.5 \mathrm{~g}$ Bactoagar per liter) was added to $0.25 \mathrm{ml}$ of the mixture of cells and bacteriophages, and the entire content was poured onto a $1 / 4 \mathrm{LB}$ plate $(5 \mathrm{~g}$ LB broth base, 6.4 $\mathrm{g} \mathrm{NaCl}$ and $15 \mathrm{~g}$ Bactoagar per liter). To estimate the number of lacZ-negative bacteriophages, $2 \mathrm{ml}$ of the mixture of cells and bacteriophages, and $22 \mathrm{ml}$ of molten $1 / 4$ LB top agar containing 0.3\% p-gal (Sigma Chemical Co., MO, USA), were mixed and poured onto four $1 / 4 \mathrm{LB}$ plates. The plates were incubated at $37^{\circ} \mathrm{C}$ for 12 hours.

\section{Construction of recombinant adenoviruses}

pNY56 was constructed by replacing the shorter XbaIBamHI fragment of pHM5 by the XbaI-BglII fragment of pNY19 (Figure 2). pAdHM4 includes the entire genome of the recombinant adenovirus vector. The plasmid pAdNY56 was constructed by replacing the shorter I-CeuIPI-SceI fragment of pAdHM4 by an I-CeuI-PI-SceI fragment of pNY56. The PacI fragment of pAdNY56 was transfected into cells of cell-line 293, which allows replication of the replication-defective adenoviruses. The recombinant adenovirus AdNY56 was prepared and purified as described previously [18]. Similarly, AdNY57 was constructed from pNY20 via pNY57 (Additional file 1), and AdNY58 was constructed from pNY21 via pNY58 (Figure 2, Additional file 1).

\section{Adenovirus infection}

Female MutaMice (7 weeks old) were obtained from Covance Research Products Inc. (Denver, PA, USA). The MutaMice were maintained under specific pathogen-free conditions in the animal faculty of the Institute of Medical Science at the University of Tokyo, Japan. After the animals were anesthetized with Nembutal (Dainippon Pharmaceutical Co., Osaka, Japan), $3 \times 10^{9}$ plaque-forming units (PFU) of the recombinant adenovirus in $200 \mu \mathrm{l}$ of PBS (137 mM NaCl, $8.10 \mathrm{mM} \mathrm{Na}_{2} \mathrm{HPO}_{4}, 2.68 \mathrm{mM} \mathrm{KCl}$, $1.47 \mathrm{mM} \mathrm{KH}_{2} \mathrm{PO}_{4}, 0.9 \mathrm{mM} \mathrm{CaCl}_{2}, 0.33 \mathrm{mM} \mathrm{MgCl}$ ) was injected into the tail-vein of each mouse using a 30-gauge needle. AdNY56 was injected into one mouse, AdNY57 was injected into two mice and AdNY58 was injected into two mice.

\section{Isolation of genomic DNA, recovery of lambda bacteriophage and measurement of mutant frequency}

Twenty-four hours after injection, the mice were sacrificed. A lobe of the liver of each animal was excised, frozen by submersion in liquid nitrogen and stored in a $1.5-\mathrm{ml}$ 


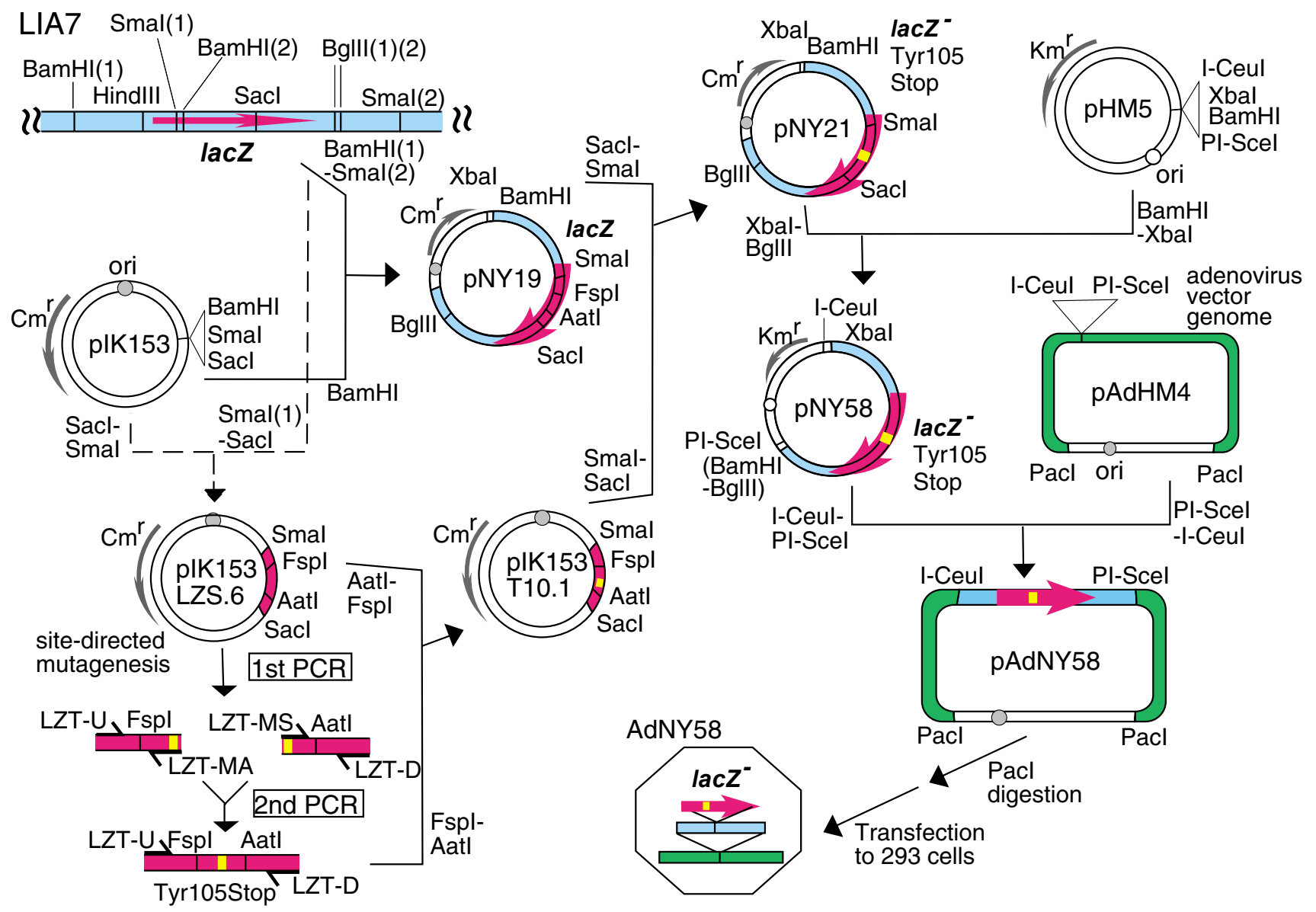

Figure 2

Construction of the recombinant adenovirus AdNY58. The bacteriophage lambda LIA7 was recovered from the MutaMouse by in vitro packaging. An Smal-Sacl fragment of LIA7 within its lacZ gene was inserted into pIKI53. The Tyr I05Stop mutation (Figure 3) was introduced into the resulting plasmid (pIKI53LZS.6) using site-directed mutagenesis by PCR as follows. The PCR products generated with the primer pair LZT-U (5'-CGAAGAGGCCCGCAC-3') and LZT-MA (5'-TAATGGGCTAGGTTACGTTGGTGTAG-3'), and the primer pair LZT-MS (5'-TAACCTAGCCCATTACGGTCAATCC-3') and LZT-D (5'-GGCAACATGGAAATCGC-3') were mixed and used as templates for the second PCR with the primer pair LTZ$U$ and LZT-D. Replacement of an Fspl-Aatll fragment of pIKI53LZS.6 by the Fspl-Aatll fragment of the resulting PCR product resulted in pIKI53 TI0.I. A BamHI-Smal fragment covering the lacZ gene of LIA7 was inserted into the BamHI site of pIKI53 (resulting in pNY19). pNY2I was made by replacing the smaller Smal-Sacl fragment of pNYI9 with the homologous Smal-Sacl fragment of pIKI53TI0.I, which carries the mutant sequence. An Xbal-Bglll fragment of pNY2I was used to replace the smaller Xbal-BamHI fragment of pHM5 (resulting in pNY58). PAdNY58 was made by replacement of the smaller I-Ceul-PI-Scel fragment of pAdHM4 with an I-Ceul-PI-Scel fragment of pNY58. The longer Pacl fragment of pAdNY58 was transfected into 293 cells. The recombinant adenovirus AdNY58 was prepared and purified from the cell culture.

plastic tube at $-80^{\circ} \mathrm{C}$. Genomic DNA was isolated from the liver tissue with phenol-chloroform and precipitated by ethanol/sodium as described in the manual for MutaMouse. Lambda bacteriophage particles were recovered from the isolated DNA by incubation with packaging extracts (Mutaplax, Epicentre, WI, USA). The lacZ-negative mutants were detected by p-gal selection as described above. Each plaque on the selective agar was recovered in $100 \mu \mathrm{l}$ of SM buffer (50 mM Tris-HCl (pH 7.5), $10 \mathrm{mM}$ $\mathrm{MgSO}_{4}, 100 \mathrm{mM} \mathrm{NaCl}$ and $0.01 \%$ gelatin). In order to verify the lacZ-negative phenotype, each isolate was assayed on agar with X-gal using a spot assay as follows. BIK2206 was grown in LB containing ampicillin $(50 \mu \mathrm{g} /$ $\mathrm{ml})$ and tetracycline $(10 \mu \mathrm{g} / \mathrm{ml})$. Twice-concentrated cul- 
ture $(1.25 \mathrm{ml})$ was mixed with $6 \mathrm{ml}$ molten LB/MM agar (100 ml LB medium, $0.75 \mathrm{~g}$ Bactoagar, $10 \mathrm{mM} \mathrm{MgSO}_{4}$, $0.2 \%$ maltose and $0.35 \mathrm{mg} / \mathrm{ml} \mathrm{X-gal)} \mathrm{and} \mathrm{spread} \mathrm{on} \mathrm{agar.}$ A $10-\mu \mathrm{l}$ aliquot of each bacteriophage sample was spotted onto these cells. The plates were incubated overnight at $37^{\circ} \mathrm{C}$. The mutant frequency was estimated by dividing the number of PFU on the selective plate (as verified with X-gal) by the number of total PFU on 1/4 LB agar.

\section{Analysis of the mutant bacteriophage DNA}

The lacZ-negative lambda bacteriophage DNA from the mice was analyzed using restriction enzymes following PCR. For the lacZ-negative lambda DNA from the AdNY57-treated mouse, PCR was carried out with the primer pair LG-1 (5'-TACCGGCGATGAGCGAAC-3') and LG-2 (5'-CTCCAGGTAGCGAAAGCC-3'). The 288-bp product was purified by ethanol/sodium precipitation, digested with TfiI (New England Biolabs, Beverly, MA, USA) (recognition site, 5'-G|AWTC-3' (W = A or T) ) at $65^{\circ} \mathrm{C}$ and analyzed using agarose electrophoresis. The mutant sequence was resistant to TfiI, while the wild-type sequence was sensitive, yielding 204 and 84 bp fragments. The primer pair Lam-1 (5'-TACTGTCGTCGTCCCCTC-3') and Lam-2 (5'-CGCAGATGAAACGCCGAGT-3') was used for the lacZ-negative lambda DNA from the AdNY58treated mouse. The 213-bp PCR product was digested with XspI (Takara Bio Inc., Shiga, Japan) (recognition site, $\left.5^{\prime}-\mathrm{C} \mid \mathrm{TAG}-3^{\prime}\right)$ at $37^{\circ} \mathrm{C}$ and analyzed using agarose electrophoresis. The wild-type sequence was resistant to XspI, while the mutant sequence was sensitive, yielding 146 and 67 bp fragments.

\section{Results \\ Experimental design for the detection of gene targeting in vivo}

Figure 1 illustrates our experimental design for the sensitive detection of gene targeting in vivo. The MutaMouse carries approximately 40 copies of bacteriophage lambda gt10lacZ on a chromosome $[6,19]$. The single integration site is located in band $\mathrm{C}$ on chromosome 3 [20]. Our target sequence was the wild-type lac $Z$ gene. The donor DNA was delivered to the liver cell nuclei by tail-vein injection of the recombinant adenovirus. Genomic DNA was isolated from the liver and its in vitro packaging allowed the recovery of the lambda genome in viable bacteriophage particles. A lacZ-negative mutant bacteriophage was selected as a plaque-former in an Escherichia coli mutant defective in the galE gene on an agar plate containing p-gal. This chemical is converted by the lac $Z$ gene product (beta-galactosidase) into UDP-galactose, which accumulates in the absence of the GalE protein to induce cell death. The ratio of the mutant plaque-formers to the total plaque-formers was used to estimate the fraction of the mutated gene. The mutant gene was further analyzed using restriction enzymes.
Replication-defective recombinant adenoviruses constructed by an in vitro-ligation method were used to deliver the donor DNA [18,21]. Figure 3 shows the structure of the recombinant adenoviruses used in the present study (see Figure 2, Additional file 1, and Materials and methods for further details). An 8077-bp fragment of lambda gt 10lac $Z$ was inserted into the E1 deletion site of the mutant adenovirus [18,21]. AdNY56 had wild-type lacZ, while AdNY57 and AdNY58 had a point mutation in lacZ (Figure 3B).

AdNY57 was constructed so as to introduce a point mutation at the active site of LacZ. The target sequence was the 5' GAA that codes for Glu461, which is essential for the activity of LacZ [22,23]. AdNY57 was expected to change its second base (that is, the 1437 th base) from A to $G$, thereby generating the Glu461Gly mutant, which shows a 76-fold decrease in activity [23]. The mutant and wildtype sequences can be distinguished using the restriction enzyme TfiI (Figure 3B).

AdNY58 was constructed so as to introduce a point mutation at the 5' TAT that codes for Tyr105. AdNY58 was expected to change its third base (that is, the 369th base) from $\mathrm{T}$ to $\mathrm{G}$, thereby generating the Tyr105Stop mutant. The mutant and wild-type sequences can be distinguished using the restriction enzyme XspI (Figure 3B).

\section{Control experiments}

We demonstrated that lac $Z$ mutants that were predicted to be generated by the recombinant adenovirus could be selected with p-gal as follows. Bacteriophage lambda strains carrying the mutations were produced by transferring each mutation on a plasmid back to lambda through homologous recombination in $\mathrm{E}$. coli (as detailed in Materials and methods). The two bacteriophage strains, lambda gt10lacZ- Tyr105Stop (LIA11) and lambda gt10lacZ- Glu461Gly (LIA15), were then used in the p-gal selection. As shown in Table 1, lambda with wild-type lac Z showed a plaque-formation efficiency of less than $1 /$ 10,000 on the selective agar relative to that on the nonselective agar. By contrast, each of the mutant lambda strains showed similar or slightly decreased plaque-formation efficiency on the selective agar. We concluded that the expected targeted product with AdNY57 and AdNY58, if it was produced, should be selected and measured using the p-gal-selection procedure.

\section{Delivery of donor DNA and measurement of mutant frequency}

The recombinant adenovirus particles $\left(3 \times 10^{9}\right.$ PFU in 200 $\mu \mathrm{l}$ of PBS) were injected into the tail-vein of a MutaMouse. It is well established that the adenovirus genome accumulates in the liver cell nuclei after tail-vein injection $[12,13]$. Most of the hepatocyte nuclei are expected to receive sev- 
A.

Recombinant adenovirus (AdNY57)

Lambda transgene ( $\lambda$ gt10 lacZ ) in mouse genome

B.

Wild type AdNY57

Glu461

- AAT GAA TCA -

— TTA CTT AGT -

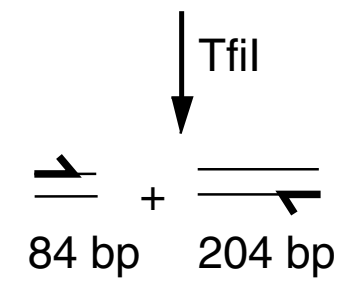

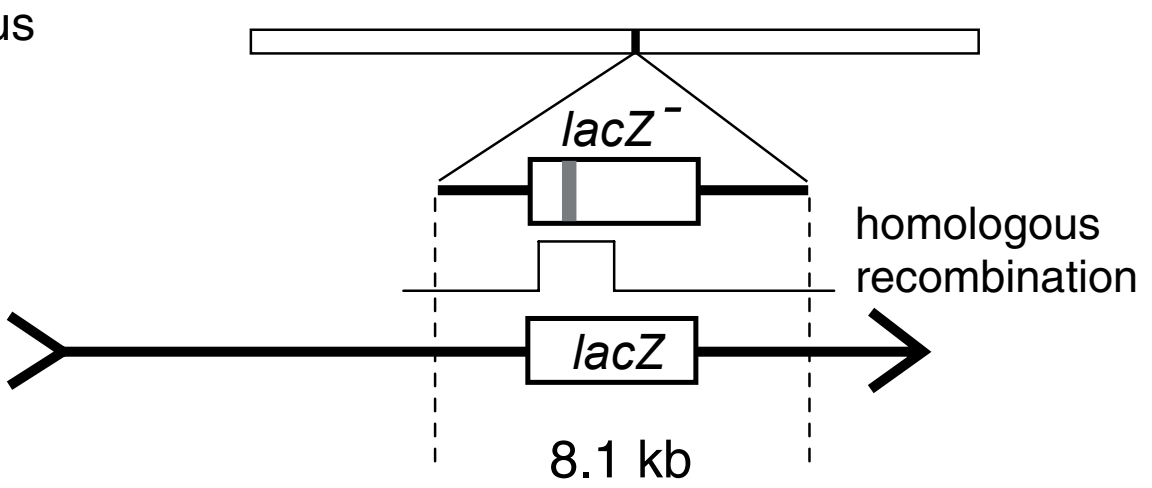

$8.1 \mathrm{~kb}$

Glu461GIy
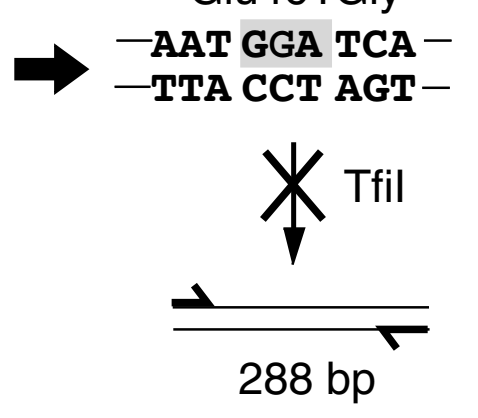

Wild type

Tyr105

$\begin{aligned} & \text { - ACC TAT CCC }- \\ & \text { - TGG ATA GGG- }\end{aligned} \rightarrow-$ - ACC TAG CCC -
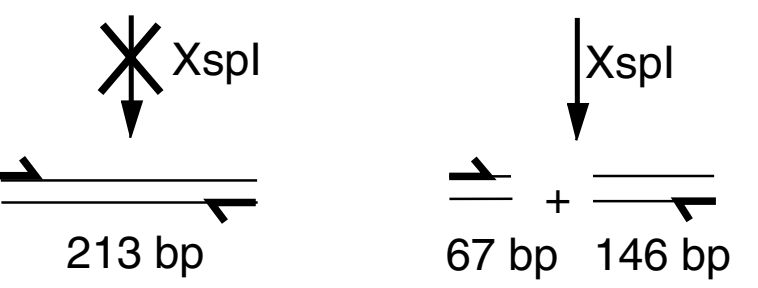

Figure 3

Design for gene targeting and its detection. (A) The donor carrying the mutant lac $Z$ gene is inserted into an adenovirus vector. The lac $Z$ mutation will be transferred to the lac $Z$ gene of the lambda transgene in the mouse genome. (B) Expected sequence changes and their detection using restriction analysis.

Table I: Selection efficiency of lambda lacZ-negative mutants

\begin{tabular}{|c|c|c|c|c|}
\hline Lambda & Genotype & Titer & $\begin{array}{c}\text { Titer on p-gal selective } \\
\text { plate }\end{array}$ & $\begin{array}{l}\text { Relative plaque } \\
\text { formation }\end{array}$ \\
\hline LIA7 & $\operatorname{lac} Z^{+}$ & $2.2 \times 10^{10}$ & $1.9 \times 10^{6}$ & $8.6 \times 10^{-5}$ \\
\hline LIAII & lacZ' (Tyr I05Stop) & $9.6 \times 10^{10}$ & $8.8 \times 10^{10}$ & $9.2 \times 10^{-1}$ \\
\hline LIAI 5 & lacZ- (Glu46IGly) & $1.4 \times 10^{10}$ & $1.3 \times 10^{10}$ & $9.1 \times 10^{-1}$ \\
\hline
\end{tabular}

eral copies of the adenovirus genome under these conditions (see Discussion). After 24 hours, the liver was excised from the MutaMouse, genomic DNA was isolated from the liver tissue and the lambda genome was recovered as a bacteriophage particle by in vitro packaging. The
lacZ-negative phage was detected selectively on agar with p-gal. The plaques on these selective plates were isolated and the LacZ-negative phenotype was confirmed on agar plates containing X-gal. The mutant frequency was estimated as the fraction of the lacZ-negative phage (Table 2). 
The control mouse (animal number 0) received no injections.

The mutant frequencies of the AdNY56-injected and control mice were similar (Table 2, Experiment 1), and did not differ significantly from those reported previously using this method (see [15] and the references cited therein). No significant increase in the mutant form of the gene was induced by injection of the recombinant adenovirus: the mutant frequency of the AdNY57- and AdNY58injected mice was similar to that of the control mouse, which was approximately 1/10,000 (Table 2).

All of the lacZ-negative bacteriophages were purified and their lacZ genes were analyzed using restriction-enzyme treatment of the PCR products (Figure 4). As shown in Figures $3 \mathrm{~B}$ and $4 \mathrm{~A}$, the PCR product of the Glu461Gly mutant, as predicted from the AdNY57 injection, could not be cut with TfiI. By contrast, the wild-type and most of the other possible mutants could be cut with TfiI. In fact, all of the lacZ-negative bacteriophages from the AdNY57injected mouse were cleavable with this restriction enzyme. As shown in Figure $3 \mathrm{~B}$ and $4 \mathrm{~B}$, the PCR product of the Tyr105Stop mutant, as predicted from the AdNY58 injection, could be cut with XspI. By contrast, the wildtype and most of the other mutants could not be cut with XspI. None of the lacZ-negative bacteriophages from the AdNY58-injected mice were cleavable with this restriction enzyme.

We did not detect the expected gene replacement in any of the isolates. Moreover, the gene-correction frequency by these adenovirus constructs was shown to be less than 1 / 20,000 in the present system.

\section{Discussion}

Here we attempted to perform gene targeting in a transgenic mouse system that allowed the sensitive detection of mutagenesis by various agents, such as those directly interacting with DNA in the liver and other organs $[24,25]$. The limit of sensitivity in this system was $1 /$ 20,000 (see also [15]). This procedure might provide an alternative to the PCR-based assay for gene targeting in vivo, although our initial trials did not detect any of the expected recombinants.

In the present system, the sensitivity appeared to be limited by the high level of spontaneous mutagenesis in the target gene. The MutaMouse system was produced to detect mutagenesis at numerous sites within a gene, rather than to study gene targeting. Experimental designs involving the specific selection of homologous recombination events, such as those used in the previous work in vitro [7], would therefore be preferred.
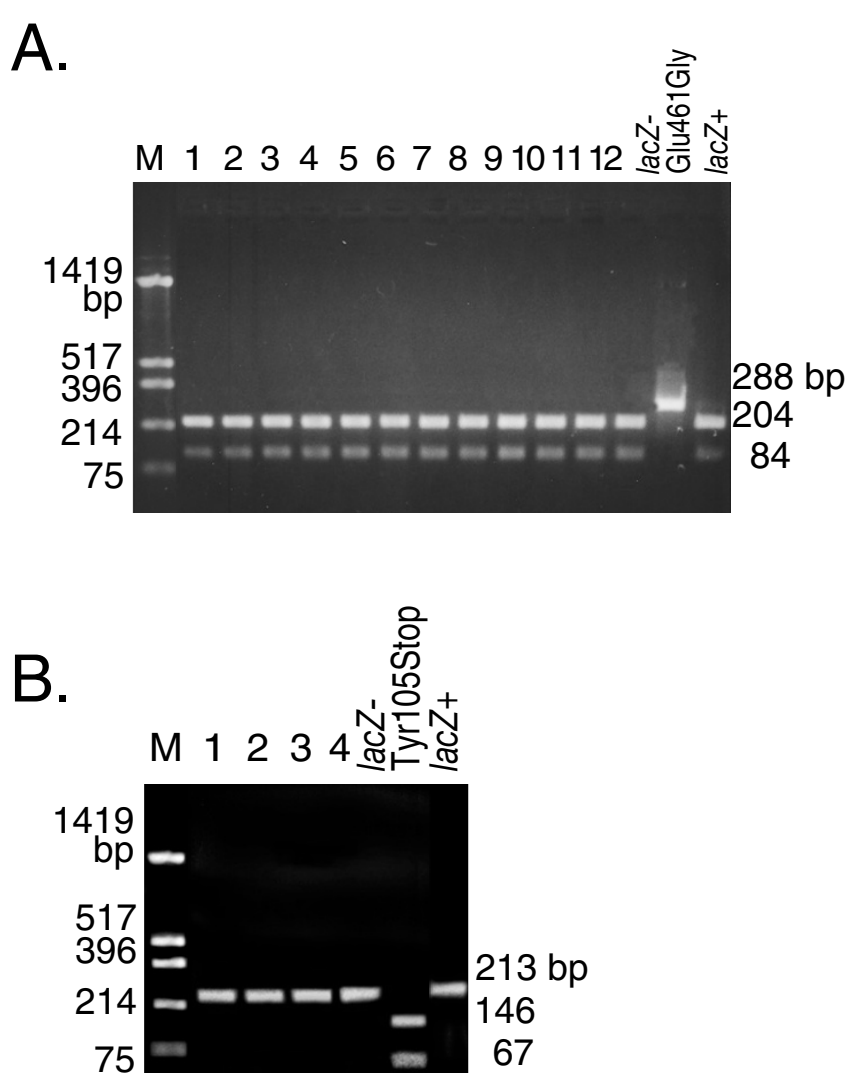

\section{Figure 4}

Restriction analysis of the lacZ-negative gene from mice treated with a recombinant adenovirus. (A) AdNY57-injected mouse. The PCR product of the lambda bacteriophage DNA with primers that flank the target site is 288 bp long. The wild-type PCR product is cut with Tfil into 84 and 204 bp fragments, whereas the Glu46I Ala mutant PCR product is not cut. Lane M: Marker DNA prepared by Hinfl digestion of the plasmid pUCI 9; I-12, lacZ-negative bacteriophages from animal number 2; lac $Z^{+}$: Lambda bacteriophage recovered from control mouse; lacZ-Glu46I Gly: lambda bacteriophage LIAI5. (B) AdNY58-injected mouse. The PCR product of the lambda bacteriophage DNA with primers that flank the target site is 213 bp long. The Tyr 105Stop mutant PCR product is cut with Xspl into I46 and 67 bp fragments, whereas the wild-type product is not. Lane M: Marker DNA prepared by Hinfl digestion of plasmid pUC I 9; I-4, lacZ-negative bacteriophages from animal number 3; lac $Z^{+}$: Lambda bacteriophage recovered from control mouse; lacZ-Tyr I05Stop: lambda bacteriophage LIAI I.

Also, in the present system, a successful gene-targeting event would not be distinguishable in the phenotype of the mouse cell. In transgenic mice with a single copy of the mutant lacZ gene [26], correction to the wild-type 
Table 2: Detection of lacZ' phage

\begin{tabular}{|c|c|c|c|c|c|c|c|c|}
\hline $\begin{array}{l}\text { Packaging } \\
\text { exp. }\end{array}$ & RAd & Genotype & $\begin{array}{l}\text { Animal } \\
\text { number }\end{array}$ & Packaging & $\begin{array}{c}\text { Total number } \\
\text { of plaque } \\
\text { formers }\end{array}$ & $\begin{array}{l}\text { lacZ- } \\
\text { plaques }\end{array}$ & Mutant Frequency & $\begin{array}{l}\text { Expected } \\
\text { genotype }\end{array}$ \\
\hline \multirow[t]{8}{*}{ I } & None & Not relevant & $\# 0$ & Tube I & $4.5 \times 10^{4}$ & 4 & $8.9 \times 10^{-5}$ & n.t. \\
\hline & & & & Tube 2 & $3.2 \times 10^{4}$ & 3 & $9.4 \times 10^{-5}$ & n.t. \\
\hline & & & & Tube 3 & $8.5 \times 10^{4}$ & 8 & $9.4 \times 10^{-5}$ & n.t. \\
\hline & & & & & & & average $9.2 \times 10^{-5}$ & \\
\hline & AdNY56 & lac $Z^{+}$ & $\# 1$ & Tube 4 & $8.5 \times 10^{4}$ & 8 & $9.4 \times 10^{-5}$ & n.t. \\
\hline & & & & Tube 5 & $6.4 \times 10^{4}$ & 3 & $4.7 \times 10^{-5}$ & n.t. \\
\hline & & & & Tube 6 & $8.8 \times 10^{4}$ & I & $1.1 \times 10^{-5}$ & n.t. \\
\hline & & & & & & & average $5.1 \times 10^{-5}$ & \\
\hline \multirow[t]{8}{*}{2} & None & Not relevant & $\# 0$ & Tube 7 & $4.9 \times 10^{4}$ & 5 & $10 \times 10^{-5}$ & n.t. \\
\hline & & & & Tube 8 & $6.6 \times 10^{4}$ & 4 & $6.1 \times 10^{-5}$ & n.t. \\
\hline & & & & Tube 9 & $5.1 \times 10^{4}$ & 10 & $20 \times 10^{-5}$ & n.t. \\
\hline & & & & & & & average $12 \times 10^{-5}$ & \\
\hline & AdNY57 & lacZ- (Glu46I Gly) & \#2 & Tube 10 & $3.8 \times 10^{4}$ & 6 & $16 \times 10^{-5}$ & $0 / 6$ \\
\hline & & & & Tube II & $3.0 \times 10^{4}$ & 7 & $23 \times 10^{-5}$ & $0 / 7$ \\
\hline & & & & Tube 12 & $4.5 \times 10^{4}$ & 9 & $20 \times 10^{-5}$ & $0 / 9$ \\
\hline & & & & & & & average $20 \times 10^{-5}$ & total $0 / 22$ \\
\hline \multirow[t]{8}{*}{3} & None & Not relevant & $\# 0$ & Tube 13 & $3.7 \times 10^{4}$ & 6 & $16 \times 10^{-5}$ & n.t. \\
\hline & & & & Tube 14 & $6.0 \times 10^{4}$ & 5 & $8.3 \times 10^{-5}$ & n.t. \\
\hline & & & & Tube 15 & $4.4 \times 10^{4}$ & 4 & $9.1 \times 10^{-5}$ & n.t. \\
\hline & & & & & & & average $11 \times 10^{-5}$ & \\
\hline & AdNY57 & lacZ' (Glu46IGly) & \#2 & Tube 16 & $1.3 \times 10^{4}$ & 9 & $69 \times 10^{-5}$ & $0 / 9$ \\
\hline & & & & Tube 17 & $3.9 \times 10^{4}$ & 19 & $49 \times 10^{-5}$ & $0 / 19$ \\
\hline & & & & Tube 18 & $6.5 \times 10^{4}$ & 26 & $40 \times 10^{-5}$ & $0 / 26$ \\
\hline & & & & & & & average $53 \times 10^{-5}$ & total $0 / 54$ \\
\hline \multirow[t]{4}{*}{4} & None & Not relevant & $\# 0$ & Tube 19 & $2.6 \times 10^{5}$ & 8 & $8.5 \times 10^{-5}$ & n.t. \\
\hline & AdNY57 & lacZ' (Glu46IGly) & \#3 & Tube 20 & $1.6 \times 10^{5}$ & 5 & $6.3 \times 10^{-5}$ & $0 / 5$ \\
\hline & & & & Tube 21 & $4.1 \times 10^{5}$ & 9 & $8.6 \times 10^{-5}$ & $0 / 9$ \\
\hline & & & & & & & average $1.5 \times 10^{-5}$ & total $0 / 14$ \\
\hline \multirow[t]{4}{*}{5} & None & Not relevant & $\# 0$ & Tube 22 & $3.3 \times 10^{4}$ & 3 & $9.1 \times 10^{-5}$ & n.t. \\
\hline & AdNY58 & lacZ- (Tyr 105 Stop) & $\# 4$ & Tube 23 & $8.6 \times 10^{4}$ & 4 & $4.7 \times 10^{-5}$ & $0 / 4$ \\
\hline & & & & Tube 24 & $3.1 \times 10^{4}$ & 3 & $9.7 \times 10^{-5}$ & $0 / 3$ \\
\hline & & & & & & & average $7.2 \times 10^{-5}$ & total $0 / 7$ \\
\hline
\end{tabular}

RAd: Recombinant adenovirus n.t.: Not tested. 
gene would result in a direct positive readout in the mouse body (for example, through staining with dye). However, as the authors admit, it would be difficult to detect the targeting events with a high sensitivity. The presence of multiple copies of the target gene would improve the sensitivity because the lac $Z^{+}$allele is dominant over, and epistatic to, the lacZ- alleles with respect to the above phenotype. The MutaMouse carries multiple (approximately 40) copies of the target gene, which amount to $0.4 \%$ of the genome. This should be able to improve the sensitivity of detection of gene targeting, although the sensitivity is limited by spontaneous mutagenesis. In addition, the presence of tandem repeats might have other types of negative effect on gene targeting, as detailed below.

How efficient is adenovirus infection and delivery to the hepatocyte nucleus? Tail-vein injection is an established method for the delivery of adenovirus to liver cells. The average copy number of a replication-defective recombinant adenovirus genome per liver cell has been estimated as 14-28 copies using Southern hybridization after tail-vein injection of $5 \times 10^{9} \mathrm{PFU}$ of the virus [12]. This corresponds to $40 \%$ of the injected adenovirus. Fluorescence in situ hybridization revealed that, after tail-vein injection of $2 \times 10^{9} \mathrm{PFU}$, all of the hepatocyte nuclei had 1-100 copies of a recombinant adenovirus genome, with an average of 20 copies [27]. After tail-vein injection of 2 $\times 10^{8}$ PFU of a recombinant adenovirus with the lacZ expression cassette, $40 \%$ of the hepatocytes expressed beta-galactosidase [13]. We assumed that the majority of the liver cells received several copies of the adenovirus genome, at least sufficient for gene expression, after injecting $3 \times 10^{9} \mathrm{PFU}$ in our experiment. (We cannot raise the titer any more because of the toxicity of the virus.) This type of information can be confirmed by Southern hybridization and fluorescence in situ hybridization.

The gene-targeting frequency with recombinant adenoviruses in vitro varies from $\sim 10^{-7}-10^{-4}$ per cell $[7,8,28]$. We did not detect any signal using recombinant adenovirus for gene delivery in the mouse liver. In order to achieve gene targeting in vivo using an adenovirus vector or any other means, it will be necessary to increase the frequency of gene targeting. So how can we achieve this goal?

The efficiency of gene targeting in vitro varies from one locus to another $[29,30]$. Such locus-dependence might reflect drastic effects of the chromatin structure on the frequency of homologous recombination [30,31]. Thus, the target transgene could be placed at a different locus that is known to be a hot spot in gene targeting in embryonic stem (ES) cells.
Repetitive sequences are methylated in the mouse genome [32]. Ikehata and colleagues suggested that the whole coding region of the MutaMouse lac $Z$ transgene is methylated to a high degree at every CpG site [33]. One possible reason for this phenomenon is that the CpG content of the lacZ gene (9\%) [34] is much higher than the average CpG content of the mouse genome ( 1\%) [35]. Methyl-CpG binding protein 2 (MeCP2) might bind to methylated CpG and somehow compact chromatin [36]. Furthermore, Manuelidis analyzed the structure of a mouse chromosome bearing a huge $(\sim 11 \mathrm{Mb})$ insert of a tandemrepeated transgene ( $\sim 1,000$ copies) [37]. This transgene was localized on an arm of chromosome 3 at a distance from the centromere. According to Manuelidis, the transgene is heterochromatic and highly condensed. Therefore, the MutaMouse transgene might be heterochromatic. The accessibility of nucleases to the heterochromatic structure is lower than that of euchromatin $[38,39]$. Reducing the copy number of the transgene and/ or using another transgene that is lower in CpG content might increase gene targeting, although the decrease in copy number might affect the sensitivity of detection. An important experiment that can be done is to test whether the coding region of the MutaMouse lac $\mathrm{Z}$ transgene is really heterochromatic, using, for example, CHIP assay with the antibody against the methylated histones and PCR primers on the lac Z genes.

Chromosome replication is known to stimulate homologous recombination. Partial hepatectomies in mice might stimulate liver cell proliferation and DNA replication, which in turn might stimulate recombination. Hara et al. (1999) reported that partial hepatectomies increased mutagenesis with $N$-ethyl-N-nitrosourea, which is a direct-acting DNA-ethylation agent, in the MutaMouse [40].

It might be easier to modify the donor DNA than the recipient DNA. One can generate recombinogenic damage on the donor DNA. Irradiating adenovirus particles with ultraviolet light of $1500 \mathrm{~J} / \mathrm{m}^{2}$ resulted in an approximately three-fold increase in their mutual homologous recombination [41]. Recombinogenic cross-links are induced by some mutagens, such as psoralens, cisplatin (cis-diamminedichloroplatinum) and mitomycin C [42]. Such agents, both mutagenic and recombinogenic, might be suitable for gene targeting in vivo if they are shown to be active in mutagenesis in a transgenic-reporter mouse system. The effect of such recombinogenic damage might be much larger with replication-defective adenovirus recombinants than with replication-competent adenoviruses, because their replication-intermediates are responsible for their high recombination frequency [41,43-45]. 
The gene-targeting frequency is strongly dependent on the length of homology; the frequency increases as the homology length increases up to $10 \mathrm{~kb}$ [46-48]. If the deviation from this rule above $10 \mathrm{~kb}$ is due to the shearing and/or degradation of longer DNA after electroporation in embryonic stem cells, donor DNAs that are protected by the DNA binding proteins in the adenovirus particle might show greater length dependence over a wider range of values. Adenoviral vectors with a larger capacity for inserts, which are known as high-capacity 'gutless' vectors [49-51] might therefore be suitable for use in this approach.

\section{Conclusion}

Here we attempted to perform gene targeting in a transgenic mouse system that allowed the sensitive detection of mutagenesis. The frequency of gene targeting in the mouse liver by these recombinant adenoviruses was shown to be less than $1 / 20000$ with the sensitive and PCR-independent detection system.

\section{List of abbreviations}

PCR, polymerase chain reaction; PFU, plaque-forming unit; RFLP, restriction fragment length polymorphism; pgal, phenyl-beta-D-galactoside; X-gal, 5-bromo-4-chloro3-indlyl-beta-D-galactose

\section{Competing interests}

The author(s) declare that they have no competing interests.

\section{Authors' contributions}

$\mathrm{AI}$ carried out the injection of the recombinant adenovirus and the analysis of the mouse DNA. YN and HM constructed the recombinant adenovirus. NH injected the recombinant adenovirus to the mouse. YN constructed the experimental design as well as cloning of the part of lambda DNA from the MutaMouse genomic DNA. IK provided the original experimental idea and coordinated the experimental design. All authors read and approved the final manuscript.

\section{Additional material}

\section{Additional file 1}

Bacterial strains, plasmids, bacteriophage strains and recombinant adenovirus constructs.

Click here for file

[http://www.biomedcentral.com/content/supplementary/14790556-3-8-S1.DOC]

\section{Acknowledgements}

Ms. Kuniko Iwasaki and Dr. Ryuichi Miura from the Laboratory Animal Research Center of the Institute of Medical Science, Japan, guided us in our manipulation of the mice. Dr. Noriko Takahashi from our laboratory helped with the maintenance of the mice. Dr. Yoichiro Iwakura of the Institute of Medical Science provided critical comments on an early version of the manuscript. This work was supported by grants from the Ministry of Education, Culture, Sports, Science and Technology (MEXT) of Japan (No.0828 102: General Mechanisms of DNA Recombination Repair. 19961999) and the Japan Owners Association (JOA) (1999-2002) as arranged by the Japan Society for Gene Therapy.

\section{References}

I. Capecchi MR: Altering the genome by homologous recombination. Science 1989, 244:1288-1292.

2. Yanez RJ, Porter AC: Therapeutic gene targeting. Gene Ther 1998, 5:149-159.

3. Kren BT, Bandyopadhyay P, Steer CJ: In vivo site-directed mutagenesis of the factor IX gene by chimeric RNA/DNA oligonucleotides. Nat Med 1998, 4:285-290.

4. Kren BT, Parashar B, Bandyopadhyay P, Chowdhury NR, Chowdhury JR, Steer CJ: Correction of the UDP-glucuronosyltransferase gene defect in the gunn rat model of crigler-najjar syndrome type I with a chimeric oligonucleotide. Proc Natl Acad Sci USA 1999, 96:10349-10354.

5. Taubes G: Gene therapy. The strange case of chimeraplasty. Science 2002, 298:2116-2120.

6. Gossen JA, de Leeuw W], Tan CH, Zwarthoff EC, Berends F, Lohman $\mathrm{PH}, \mathrm{Knook} \mathrm{DL}$, Vijg J: Efficient rescue of integrated shuttle vectors from transgenic mice: a model for studying mutations in vivo. Proc Natl Acad Sci USA 1989, 86:7971-7975.

7. Fujita A, Sakagami K, Kanegae Y, Saito I, Kobayashi I: Gene targeting with a replication-defective adenovirus vector. J Virol 1995, 69:6180-6190.

8. Mitani K, Wakamiya M, Hasty P, Graham FL, Bradley A, Caskey CT: Gene targeting in mouse embryonic stem cells with an adenoviral vector. Somat Cell Mol Genet 1995, 2 I:22I-23I.

9. Doerfler $\mathrm{W}$ : The fate of the DNA of adenovirus type 12 in baby hamster kidney cells. Proc Natl Acad Sci USA 1968, 60:636-643

10. Harui A, Suzuki S, Kochanek S, Mitani K: Frequency and stability of chromosomal integration of adenovirus vectors. J Virol 1999, 73:6|4I-6I46.

II. Volpers C, Kochanek S: Adenoviral vectors for gene transfer and therapy. J Gene Med 2004, 6(SuppI I):SI 64-I 7 I.

12. Vrancken Peeters MJ, Perkins AL, Kay MA: Method for multiple portal vein infusions in mice: quantitation of adenovirusmediated hepatic gene transfer. Biotechniques 1996, 20:278-285.

13. Nakatani T, Kuriyama S, Tominaga K, Tsujimoto T, Mitoro A, Yamazaki M, Tsujinoue H, Yoshiji H, Nagao S, Fukui H: Assessment of efficiency and safety of adenovirus mediated gene transfer into normal and damaged murine livers. Gut 2000, 47:563-570.

14. Cormack B: Mutagenesis by the polymerase chain reaction. In Current protocols in moecular biology Volume I. Edited by: Ausubel MF, Brent R, Kingston RE, Moore DD, Seidman JG, Smith JA, Struho K. John Wiley and Sons, Inc; 1991:8.5.I-8.5.9.

15. Ino A, Yamamoto S, Kaneda Y, Kobayashi I: Somatic gene targeting with RNA/DNA chimeric oligonucleotides: an analysis with a sensitive reporter mouse system. J Gene Med 2004, 6:1272-1280.

16. Dean SW, Myhr B: Measurement of gene mutation in vivo using Muta Mouse and positive selection for lacZ- phage. Mutagenesis 1994, 9: 183-185.

17. Gossen JA, Vijg J: A selective system for lacZ-phage using a galactose-sensitive E.coli host. Biotechniqnics 1993, 14:326-330.

18. Mizuguchi H, Kay MA: Efficient construction of a recombinant adenovirus vector by an improved in vitro ligation method. Hum Gene Ther 1998, 9:2577-2583.

19. Blakey DH, Douglas GR, Huang KC, Winter H]: Cytogenetic mapping of lambda gt 10 lac $Z$ sequences in the transgenic mouse strain 40.6 (Muta Mouse). Mutagenesis 1995, 10:145-148.

20. Swiger RR, Myhr B, Tucker JD: The LacZ transgene in MutaMouse maps to chromosome 3. Mutat Res 1994, 325: I 45- I 48.

21. Mizuguchi H, Kay MA: A simple method for constructing EIand EI/E4-deleted recombinant adenoviral vectors. Hum Gene Ther 1999, 10:2013-2017. 
22. Jacobson RH, Zhang XJ, DuBose RF, Matthews BW: Three-dimensional structure of beta-galactosidase from $E$. coli. Nature 1994, 369:761-766.

23. Cupples CG, Miller JH: Effects of amino acid substitutions at the active site in Escherichia coli beta-galactosidase. Genetics 1988, I 20:637-644.

24. Cosentino L, Heddle JA: A comparison of the effects of diverse mutagens at the lacZ transgene and Dlb-I locus in vivo. Mutagenesis 1999, 14:1 13-119.

25. Krebs O, Favor J: Somatic and germ cell mutagenesis in lambda lacZ transgenic mice treated with acrylamide or ethylnitrosourea. Mutat Res 1997, 388:239-248.

26. Nickerson HD, Colledge WH: A LacZ-based transgenic mouse for detection of somatic gene repair events in vivo. Gene Ther 2004, I I: | 35 I- I357.

27. Schowalter DB, Tubb JC, Liu M, Wilson CB, Kay MA: Heterologous expression of adenovirus E3-gp I $9 \mathrm{~K}$ in an $\mathrm{EI}$ a-deleted adenovirus vector inhibits MHC I expression in vitro, but does not prolong transgene expression in vivo. Gene Ther 1997, 4:35I-360.

28. Wang Q, Taylor MW: Correction of a deletion mutant by gene targeting with an adenovirus vector. Mol Cell Biol 1993 13:9|8-927.

29. Bird D, Bradshaw R: Gene targeting is locus dependent in the filamentous fungus Aspergillus nidulans. Mol Gen Genet 1997. 255:219-225.

30. Petes TD: Meiotic recombination hot spots and cold spots. Nat Rev Genet 200I, 2:360-369.

31. Ohta K, Shibata T, Nicolas A: Changes in chromatin structure at recombination initiation sites during yeast meiosis. Embo J 1994, I 3:5754-5763.

32. Lau S, Jardine K, McBurney MW: DNA methylation pattern of a tandemly repeated LacZ transgene indicates that most copies are silent. Dev Dyn 1999, 215:126-138.

33. Ikehata $H$, Takatsu $M$, Saito $Y$, Ono T: Distribution of spontaneous CpG-associated G:C --> A:T mutations in the lacZ gene of Muta mice: effects of CpG methylation, the sequence context of CpG sites, and severity of mutations on the activity of the lacZ gene product. Environ Mol Mutagen 2000, 36:30 I-3II.

34. Chevalier-Mariette C, Henry I, Montfort L, Capgras S, Forlani S, Muschler J, Nicolas JF: CpG content affects gene silencing in mice: evidence from novel transgenes. Genome Biol 2003, 4:R53.

35. Takai D, Jones PA: Comprehensive analysis of CpG islands in human chromosomes 21 and 22. Proc Natl Acad Sci USA 2002, 99:3740-3745.

36. Bowen NJ, Palmer MB, Wade PA: Chromosomal regulation by MeCP2: structural and enzymatic considerations. Cell Mol Life Sci 2004, 61:2163-2167.

37. Manuelidis L: Heterochromatic features of an II-megabase transgene in brain cells. Proc Natl Acad Sci USA 1991, 88: $1049-1053$.

38. Vega-Palas MA, Venditti S, Di Mauro E: Heterochromatin organization of a natural yeast telomere. Changes of nucleosome distribution driven by the absence of Sir3p. J Biol Chem 1998 , 273:9388-9392.

39. Ye F, Signer ER: RIGS (repeat-induced gene silencing) in Arabidopsis is transcriptional and alters chromatin configuration. Proc Natl Acad Sci USA 1996, 93:1088I-10886.

40. Hara T, Sui H, Kawa Kami K, Shimada Y, Shibuya T: Partial hepatectomy strongly increased the mutagenicity of $\mathbf{N}$-ethyl-N nitrosourea in Mutamouse liver. Environ Mol Mutagen 1999, 34: $121-123$

41. Rainbow AJ, Castillo JE: Homologous recombination of adenovirus DNA in mammalian cells: enhanced recombination following UV-irradiation of the virus. Mutat Res 1992 274:20I-2I0.

42. Wang YY, Maher VM, Liskay RM, McCormick J): Carcinogens can induce homologous recombination between duplicated chromosomal sequences in mouse $\mathbf{L}$ cells. Mol Cell Biol 1988 , 8: $196-202$

43. Flint SJ, Berget SM, Sharp PA: Characterization of singlestranded viral DNA sequences present during replication of adenovirus types 2 and 5. Cell 1976, 9:559-57I.
44. Epstein LH, Young CS: Adenovirus homologous recombination does not require expression of the immediate-early EIa gene. J Virol 199I, 65:4475-4479.

45. Young CS, Cachianes G, Munz P, Silverstein S: Replication and recombination in adenovirus-infected cells are temporally and functionally related. J Virol I984, 5 I:57| -577 .

46. Deng C, Capecchi MR: Reexamination of gene targeting frequency as a function of the extent of homology between the targeting vector and the target locus. Mol Cell Biol 1992, I 2:3365-337|.

47. Scheerer JB, Adair GM: Homology dependence of targeted recombination at the Chinese hamster APRT locus. Mol Cell Biol 1994, | 4:6663-6673.

48. Fujitani Y, Yamamoto K, Kobayashi I: Dependence of frequency of homologous recombination on the homology length. Genetics 1995, | 40:797-809.

49. Wang L, Hernandez-Alcoceba R, Shankar V, Zabala M, Kochanek S, Sangro B, Kramer MG, Prieto J, Qian C: Prolonged and inducible transgene expression in the liver using gutless adenovirus: a potential therapy for liver cancer. Gastroenterology 2004, I 26:278-289.

50. Kreppel F, Kochanek S: Long-term transgene expression in proliferating cells mediated by episomally maintained highcapacity adenovirus vectors. J Virol 2004, 78:9-22.

5I. Stilwell JL, McCarty DM, Negishi A, Superfine R, Samulski RJ: Development and characterization of novel empty adenovirus capsids and their impact on cellular gene expression. J Virol 2003, 77:|288|-|2885

52. Casadaban MJ, Cohen SN: Analysis of gene control signals by DNA fusion and cloning in Escherichia coli. J Mol Biol 1980, I38: |79-207.

53. Takahashi NK, Kusano K, Yokochi T, Kitamura Y, Yoshikura H, Kobayashi I: Genetic analysis of double-strand break repair in Escherichia coli. J Bacteriol |993, I75:5|76-5|85.

54. Huynh T, Young R, Davis R: Constructing and Screening cDNA Libraries in $\lambda$ gt 10 and $\lambda$ gt I I. In DNA cloning. Volume I a practical approach Edited by: Glover D. Washinton DC: IRL PRESS; 1984:49-78.

55. Naito Y, Naito T, Kobayashi I: Selfish restriction modification genes: resistance of a resident $R / M$ plasmid to displacement by an incompatible plasmid mediated by host killing. Biol Chem 1998, 379:429-436.

56. Yanisch-Perron C, Vieira J, Messing J: Improved MI 3 phage cloning vectors and host strains: nucleotide sequences of the MI3mpI 8 and pUCI9 vectors. Gene 1985, 33:103-II9.

Publish with Biomed Central and every scientist can read your work free of charge

"BioMed Central will be the most significant development for disseminating the results of biomedical research in our lifetime. "

Sir Paul Nurse, Cancer Research UK

Your research papers will be:

- available free of charge to the entire biomedical community

- peer reviewed and published immediately upon acceptance

- cited in PubMed and archived on PubMed Centra

- yours - you keep the copyright 